\title{
The Impact of Remittances on Economic Growth and Development in Africa
}

\author{
Bichaka Fayissa* \\ Middle Tennessee State University \\ Christian Nsiah \\ Black Hills State University
}

\begin{abstract}
For more than half a century, there have been heated debates on the sources of economic growth in developing economies. The perceived factors of economic growth have ranged from surplus labor to capital investment and technological change, foreign aid, foreign direct investment, investment in human capital, increasing returns from investment in new ideas and research and development. The positive or negative impacts of the above listed traditional sources of economic growth have been well documented in literature. Other researchers have also considered the importance of institutional factors such as the role of political freedom, political instability, voice and accountability on economic growth and development. Despite the increasing importance of remittances in total international capital flows, however, the direct or indirect relationship between remittances and economic growth has not been adequately studied. This study explores the aggregate impact of remittances on economic growth within the conventional neoclassical growth framework using an unbalanced panel data spanning from 1980 to 2004 for 37 African countries. We find that remittances boost growth in countries where the financial systems are less developed by providing an alternative way to finance investment and helping overcome liquidity constraints.
\end{abstract}

Key Words: Workers' Remittances, Economic Growth, Panel Data, Fixed-Effects, Random-Effects, Arellano-Bond, Quantile Regression

JEL Classification: E21 F21, G22, J61, O16

\footnotetext{
* Corresponding author: Bichaka Fayissa, Department of Economics and Finance, Middle Tennessee State University, Murfreesboro, TN 37132, U. S.A. Tel (615)898-2385, Fax (615) 898-5596

Email: bfayissa@mtsu.edu
} 


\section{The Impact of Remittances on Economic Growth and Development in Africa}

\section{Introduction}

For more than half a century, there have been heated debates on the sources of economic growth of developing economies (Lewis, 1954; Solow, 1956; Chenery and Strout, 1966; Denison, 1967; Myrdal, 1968; Harris-Todaro, 1970; Schultz, 1979; Fields, 1980; Romer, 1986; Lucas, 1988; Barro, 1991; and Easterly, 2001). The perceived sources of economic growth have ranged from surplus labor to physical capital investment and technological change, foreign aid, foreign direct investment (FDI), investment in human capital, increasing returns from investment in new ideas and research and development. Other researchers such as Owens (1987), Sen (1990), and Kaufmann, Kray, and Mastruzzi (2006) have also focused on the impact of institutional factors such as the role of political freedom, political instability, voice and accountability on economic growth and development.

For many developing countries, however, remittances represent a major part of international capital flows, surpassing foreign direct investment (FDI), export revenues, and foreign aid (Giuliano and RuizArranz, 2005). A recent World Bank (2006) study suggests that recorded remittances have grown faster than foreign direct investment, or official development assistance (See, Figure 1 below). 
Figure 1: International Capital Flows to Africa

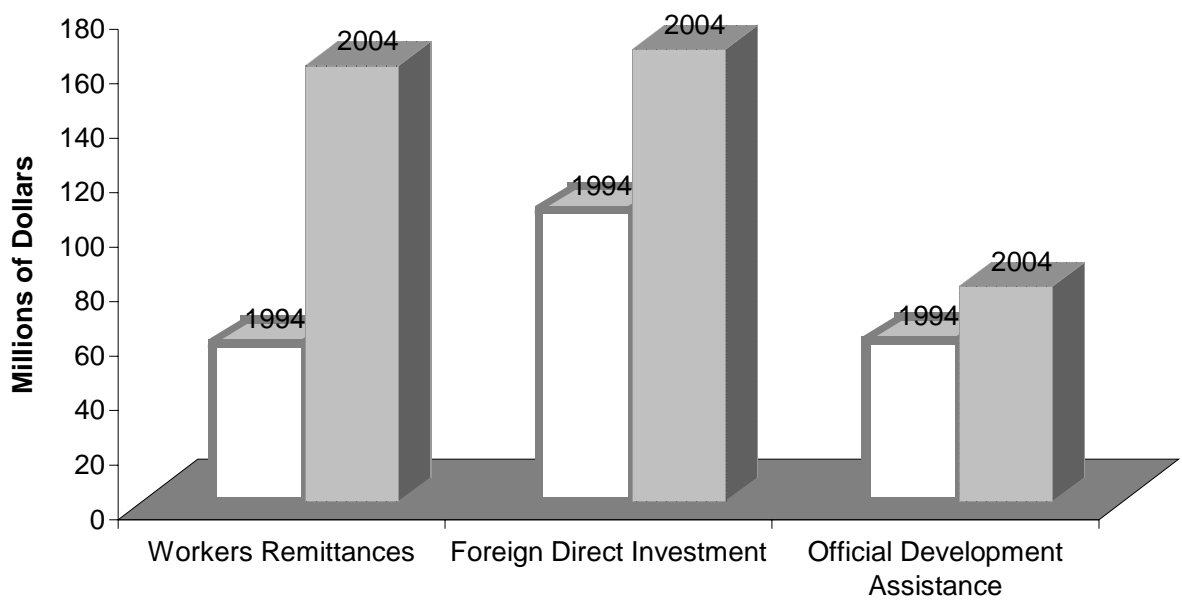

Source: Global Prospects 2006; Economic Implications of Remittances and Migration, page 88, World Bank, Washington, D.C.

Consequently, recent financial flows into developing countries in the form of remittances are receiving increased attention because of their size and impact on the economies of recipient countries. According to Gupta, et al. (2007), estimated official remittances reached a total of $\$ 188$ billion in 2005 which is twice the amount of development assistance received by emerging economies. Informal and unreported remittances could even easily add another $\$ 94$ billion to the above figure. Between 2000 and 2005, remittances to Sub-Sahara Africa (SSA) rose 55 percent to nearly $\$ 7$ billion in comparison to 81 percent increase for all developing countries as a group. In rank order, the top 10 recipients of remittances as percent of GDP in SSA are: Lesotho (with more than 25\%), Cape Verde, Guinea-Bissau, Senegal, Togo, Uganda, Comoros, Swaziland, Mauritius, and Kenya (with less than 5\%). In terms of the ratio of remittances to export earnings, the top ten countries are: Lesotho (60\%), Cape Verde, Uganda, Comoros, Senegal, Guinea-Bissau, Benin, Togo, Burkina Faso, and Kenya (about 15\%) (See Figure 2 below)

$<<$ Insert Figure 2 here $>>$. 
Despite the increasing importance of remittances in the total international capital flows, the relationship between remittances and growth, especially in SSA, has not been adequately studied. This study explores the aggregate impact of remittances on the economic growth of Sub-Sahara African countries within the conventional neoclassical growth model, using panel data spanning from 1980 to 2004 for 37 African countries. ${ }^{1}$

We also account for the traditional sources of economic growth using estimation methods that are based on simple fixed-effects and random-effects models which allow us to account for the heterogeneity of African economies and the differences in the traditional sectors' contributions to the economic growth of African economies. The contribution of our work to the empirical literature is that we provide evidence of the extent to which the remittances can spur economic growth while accounting for the conventional sources of economic growth using standard theory. Our empirical results show that remittances have statistically significant contribution to both the current level of gross domestic product and the economic growth rate of Sub-Saharan African countries as do investments in physical and human capital. Our findings suggest that remittances play a role in the economic growth of Sub-Sahara African economies by augmenting the dwindling external sources of capital in the form of foreign aid, foreign direct investment, and/ or private investments to Africa.

The rest of the paper is organized as follows. Section II provides a review of selected literature. In section III, we specify a conventional neoclassical growth model which incorporates remittances as one of the sources of growth. Section IV presents estimation results for both the fixed and random effects regressions accounting for both the country and time effects and the Arellano-Bond (2002) dynamic panel data estimates for reflecting both the dynamic nature of the data and endogeneity of some of the conventional growth sources. The last section summarizes the results, draws conclusions, and makes some policy recommendations for promoting remittances as a growth and development strategy.

\footnotetext{
${ }^{1}$ We wanted to use data for all African countries; however, only 37 countries had complete data for the variables employed in this study for the time period under consideration.
} 


\section{A Review of Selected Literature}

Based on household survey data from various African countries, few empirical studies have investigated the role of remittances in reducing poverty (Lucas and Stark, 1985; Adams, 1991; Sander, 2004; Azam and Gubert, 2005; Adam, 2006). The macroeconomic impacts of remittances have been disregarded for at least two reasons. One theoretical strand suggests that workers' remittances are mainly used for consumption purposes and, hence, have minimal impact on investment. In other words, remittances are widely viewed as compensatory transfers between family members who lost skilled workers due to migration.

Nevertheless, Stahl and Arnold (1986) argue that the use of remittances for consumption may have a positive effect on growth because of their possible multiplier effect. Moreover, remittances respond to investment opportunities in the home country as much as to charitable or insurance motives. Many migrants invest their savings in small businesses, real estate or other assets in their own country because they know the local markets better than in their host countries, or probably expecting to return in the future. In about two-thirds of developing countries, remittances are mostly profit-driven and increase when economic conditions improve back home. Such external monetary flows are particularly used for investment where the financial sector does not meet the credit needs of local entrepreneurs (Institute of Development Studies, id21 insights, \#60, January, 2006). Thus, we cannot, a priori, predict the direction of the impact of remittances $\left(R E M_{i t}\right)$ on the economic growth of Sub-Saharan African economies based on the above discussions.

\section{An Empirical Model of Economic Growth with Remittances}


In the economic growth literature, researchers have been interested in the rate at which countries close the gap between their current positions and their desired long-run growth path. To determine the responsiveness of income growth rate to remittances and the traditional the sources of economic growth such as investment in physical $\left(G C F_{i t}\right)$ and human capital $\left(E N R_{i t}\right)$, an external source of capital represented by foreign aid $\left(A I D_{i t}\right)$, openness of the economy as measured by the ratio of the sum of imports and exports to the GDP, often proxied by the terms of trade $\left(T O T_{i t}\right)$, foreign direct investment(FDI), a measure of an institutional factor often represented by the economic and political freedom index(PRI), and the impact of the initial per capita income $\left(\mathrm{INY}_{i t}\right)$, we first specify a simple double log-linear Cobb-Douglass production function as:

$\ln G D P_{i t}=\beta_{0}+\beta_{1} \ln R E M_{i t}+\beta_{2} \ln G C F_{i t}+\beta_{3} \ln A I D_{i t}+\beta_{4} \ln E N R_{i t}+\beta_{5} \ln F D I_{i t}+\beta_{6} \ln T O T_{i t}+\beta_{7} \ln I N Y_{i}+\ln \beta_{8} P R I_{i t}+\varepsilon_{i t}$

Where $\ln G D P_{i t}$ is the natural $\log$ of real GDP per capita and $\ln R E M_{i t}$ is $\log$ of remittances per capita in US\$; $\ln G C F_{i t}$ is the log of gross fixed capital formation as a percent of real GDP used as a proxy for investment in physical capital ${ }^{2}$. $\quad \ln E N R_{i t}$ is $\log$ of secondary school enrollment used as measure of investment in human capital which has a positive effect on the economic growth of developing countries (Schultz, 1980; Romer 1986; Lucas, 1988; and Barro, 1990).

The log of foreign aid $\left(A I D_{i t}\right)$ is used to capture the impact of an external source of capital on economic growth. Proponents of aid argue that overseas capital flows are necessary for the economic growth of developing countries (Chenery and Strout, 1966; Papenek, 1973; Levy, 1987; and Islam, 1992; Fayissa and El-Kaissy, 1999). On the other hand, opponents of foreign aid argue that it has a negative effect on domestic savings and economic growth in less developed countries (see, Heller, 1975 and Boone, 1994). $F D I_{i t}$ is the $\log$ of foreign direct investment used to capture the effect of external sources of

\footnotetext{
${ }^{2}$ Our specification in $\mathrm{Eq}(1)$ is based on the empirics in the new growth theory (Lucas, 1988; Barro, 1990; Benhabib and Spiegel, 1994; Grossman and Helpman, 1991; Barro and Sala-i-Martin, 1992b; Barro and Lee, 1994; and Temple, 1999).
} 
capital on growth; $T O T_{i t}$ is the log of the terms of trade for each country under consideration, measured by the ratio of the export to import price indices (See, Table 1 for detailed definitions) to capture the impact of trade, or openness of the economy on economic growth.

$\ln P R I_{i t}$ is $\log$ of a measure of the political rights index. Owen (1987) and Sen (1999) have argued that freedom (political, economic, social, transparency and security) is a necessary condition for economic growth and development. Thus, we use the $\log$ of political rights index $\left(P R I_{i t}\right)$ to capture the effect of this institutional factor. Obtained from the Freedom House's Freedom in the World Country Ratings, the political rights index goes from 1 to 7 , where 1 denotes "most free" and 7 denotes the least level of political liberty. Hence, we expect the sign of the political rights index to be negative.

The impact of the initial level of GDP per capita $\left(I N Y_{i t}\right)$ on economic growth has been controversial at best. On the one hand, Blomstrom (1996) and Casseli, et al. (1996) have found a positive relationship between growth rate and the initial level GDP per capita growth rate through its positive impact on capital formation. On the other hand, Barro (1997) has found a negative relationship between the initial GDP per capita and the GDP growth rate in a cross-country empirical study which he interprets to imply a case of conditional convergence. Consequently, we cannot, a priori, predict the sign of the initial level of GDP per capita $\left(I N Y_{\text {it }}\right)$ coefficient.

To estimate the parameters corresponding to variables of interest from the data under consideration, we employ a panel data estimation, an empirical exposition of which is provided in equation (2) below.

$$
Y_{i t}=\lambda_{i}+\gamma_{t}+\left(\mathrm{X}_{i t}\right) \varphi+\psi_{i t}
$$

where $Y_{i t}$ is the natural logarithm of real GDP per capita in country $i$ at year $t$, and $X_{i t}$ is a vector of the explanatory variables (remittances, investment in physical and human capital, foreign aid, openness, 
foreign direct investment, economic freedom index, and initial income) for country $\mathrm{i}=1,2 \ldots, \mathrm{m}$ and at time $\mathrm{t}=1,2, \ldots, \mathrm{T}, \varphi$ a scalar vector of parameters of $\beta_{1} \ldots, \beta_{7} ; \psi_{i t}$ is a classical stochastic disturbance term with $\mathrm{E}\left[\psi_{i t}\right]=0$ and $\operatorname{var}\left[\psi_{i t}\right]=\sigma_{\dot{\varepsilon}}{ }^{2}, \lambda_{\mathrm{i}}$ and $\gamma_{t}$ are country and time specific effects, respectively. Instead of a priori decision on the behavior of $\lambda_{\mathrm{i}}+\gamma_{t}$, different types of assumptions are separately imposed on the model and the one that gives robust estimates is chosen.

If we assume the country specific effects to be constant across countries and the time specific effects are not present [i.e. $\lambda_{\mathrm{i}}=\gamma_{t}$ and $\gamma_{t}=0$ )], then model (2) is estimated by the Ordinary Least Squares (OLS) method, or restricted OLS method. The second estimation technique assumes that the country specific effects are constant, but not equal (i.e. $\lambda_{\mathrm{i}}=\gamma_{t}$ and $\gamma_{t}=0$ which yields a one-way fixed effects model. The third assumption is a situation where the country effects are not constants, but rather are disturbances; the time effects are not present $\left[\right.$ i.e. $\lambda_{\mathrm{i}}=\gamma_{t}+\mathrm{w}_{\mathrm{i}}$ and $\left.\gamma_{t}=0\right]$ where $\mathrm{E}\left[\mathrm{w}_{i}\right]=0$ and $\operatorname{var}\left[\mathrm{w}_{i}\right]=$ $\sigma_{\mathrm{w}}{ }^{2}$ and $\operatorname{cov}\left[\psi_{i}, \mathrm{w}_{i}\right]=0$. In this case, model (2) is estimated by the generalized least squares (GLS) which yields random-effects model.

Given that some of the traditional factors that explains growth are either pre-determined, or endogenous, or both, and current period growth could depend on its values in the past, a dynamic variant of the fixed and random effects provided in Equation (2) above, known as the Arellano-Bond estimation (1991) is specified as follows:

$$
\Delta Y_{i t}=\alpha^{\prime} \Delta Y_{i t-1}+\beta^{\prime} \Delta X_{i t-1}+\gamma^{\prime} Z_{i t}+v_{i}+\varepsilon_{i t}
$$

where $\Delta Y_{i t}$ is first difference of the natural log of per capita income growth in country $i$ during time $t$; $\Delta Y_{i t-1}$ is lagged difference of the dependent variable, $\Delta X_{i t-1}$ is a vector of lagged level and differenced predetermined and endogenous variables, $z_{i t}$ is a vector of exogenous variables, and $\alpha, \beta$, and $\gamma$ are 
parameters to be estimated. $v_{i}$ and $\varepsilon_{\mathrm{it}}$ are assumed to be independent over all time periods in country $i$. The term $v_{i}$ represents country specific effects which are independently and identically distributed over the countries while $\varepsilon_{i t}$ noise stochastic disturbance term and is also assumed to be independently distributed. We estimate the coefficients of the variables using the Arellano-Bond (1991) Generalized Method of Moments (GMM) estimator to evaluate the joint effects of remittances and the other explanatory variables on economic growth in African countries while controlling for the potential bias due to the endogeneity of some of the regressors including the lagged dependent variable.

All data, except for the political rights index (which is taken from the Freedom House's Freedom in the World Country Ratings) are from the World Bank Development Indicators (WDI, 2006) CD. The definitions and descriptive statistics of each variable included in the model are provided in Table 1.

$<<$ Insert Table 1 here $>>$

\section{Empirical Results and Interpretations}

Several versions of equation 2 are tested in order to obtain a model which yields robust results and best fits the data. Accordingly, column 1 of Table 2 presents the estimation results of a quasi fixed-effects panel with heteroskedasticity corrected standard errors, whereas column 2 presents the estimation results for the random- effects model with bootstrap standard errors. The correction for heteroskedasticity and the presence of the initial income converts the pooled regression with heteroskedasticity corrected standard errors into a quasi fixed-effects model. Apart from the magnitude of the coefficients, the results reported in columns 1 and 2 are comparable. 
A comparison of the consistent quasi fixed-effects model with the efficient random-effects model using the Hausman specification test, rejects the random-effects estimates at $p<0.05$ in favor of the quasi fixed-effects estimates. We thus base the discussion of our findings on the more robust quasi fixedeffects results reported in column 1 of Table 2. Broadly, the results reveal the expected relationship between the GDP per capita income $\left(G D P_{i t}\right)$ and the explanatory variables i.e., the variables representing the sources of growth have the expected signs according to the a priori predictions. All the coefficients represent elasticities since we estimated a double-logarithmic model.

\section{$<<$ Insert Table 2 here $>>$}

The results from our model of choice indicate that remittance variable has a positive and statistically significant effect on the GDP per capita (at $p<.01$ ) of African countries. Accordingly, we find that a 10 percent increase in the remittances of a typical African economy would result in about 0.4 percent increase in the average per capita income. Similarly, a 10 percent increase in investment in human capital $(E N R)$ as measured by the percent secondary school enrollment increases GDP per capita by 1.6 percent, by far the main variable which spurs economic growth. Consistent with the findings of Solow (1956), Barro (1990) and Temple (1999), we also find that investment in physical capital $(G C F)$ as measured by the gross fixed capital formation as a percent of GDP has a positive and statistically significant impact on the real per capita GDP i.e., we observe that a 10 percent increase in investment in the physical capital will lead to about 1.06 percent increase in the GDP per capita.

Our results also indicate that foreign aid $(A I D)$ has a negative effect on economic growth, confirming the position of the opponents of aid (Heller, 1975; Boone, 1994; and Fayissa and El-Kaissy, 1999). However, its impact is not significant. A measure of the openness of the economy (TOT) has the expected positive sign, but it is does not have a significant impact on economic growth. We find a 
positive, but not significant relationship between the foreign direct investment $(F D I)$ and the economic growth of our sample of African countries.

On the other hand, the institutional variable $(P R I)$ used to capture the effect of political freedom shows that poor governance is an important bottleneck to the observed economic growth performances of African economies. Consistent with arguments made by Sen (1990) and Owen (1987), our estimates indicate that a 10 percentage reduction in political rights lead to about 1.34 percent reduction in per capita income. In their celebrated article, "Africa's Growth Tragedy: Policies and Ethnic Divisions," Easterly and Levine (1997) have empirically demonstrated that economic growth is affected by the quality of governance (ethnic divisions, political instability), schooling, state of the financial system, exchange markets distortions, high government deficits, and insufficient infrastructure. Finally, we find that the coefficient of the initial per capita income (GDPPC 1980) has a positively and statistically significant effect on the current level of economic growth of countries. In fact, a coefficient value of 0.9 for the initial GDP per capita (INY) implies that a 1 percent increase in INY increases the current GDP per capita by 0.9 percent. This indicates a case of non-convergence; i.e., the countries with higher percapita income in 1980 are the ones experiencing higher growth.

While results based on the fixed and random effects models in which we simultaneously account for the heterogeneity and time to time fluctuations in the economic performance of African economies are appealing, we note that some of the explanatory variables of growth are endogenous, thus confounding the results. For example, while FDI and investment in human capital $(\mathrm{SCH})$ have often been credited for their role in the economic growth of a country, there is also ample evidence (Hansen and Rand, 2006; de Mello, 1999) that the level GDP and its growth rate have feedback effects on the amount of FDI a country receives and the rate of investment in human capital formation. Given that we are mainly interested in analyzing the effect of remittances on African economic growth while accounting for the traditional growth explanatory factors that are either pre-determined (e.g., schooling) or endogenous 
(e.g., FDI), or both, we employ the Arellano-Bond dynamic panel General Method of Moments (GMM) estimator to obtain robust estimates by using levels lagged one period to serve as instruments for the endogenous variables. The Arellano-Bond dynamic GMM estimates are reported in Table 3.

In our case, the Sargan test fails to reject the null hypothesis that the over-identifying restrictions are valid while the Arellano-Bond test rejects the null hypothesis of no-first autocorrelation in the differenced residuals $\mathrm{AR}(1)$, and accepts the null hypothesis of no second order autocorrelation in the differenced residuals. Consequently, the estimated coefficients reflect the true (efficient and unbiased) relationship between growth in African per capita GDP and remittances (our variable of interests) and the traditional growth determinants that are either pre-determined, or endogenous, or both.

Based on the results from our model, we observe that the coefficients of the lagged values of GDP per capita $(P C I)$ and changes in remittances $(R E M)$ have a significant and positive impact on the growth rate of African GDP per capita. Accordingly, a 10 percent increase in remittances would lead to a 0.04 percent growth in the GDP pre capita of African economies. Accounting for the endogenous nature of the traditional growth explaining factors, we find that while foreign direct investment $(F D I)$, the terms of trade $(T O T)$, and the institutional variable proxied by the political rights index $(P R I)$ were not significant, investment in physical $(G C F)$, and the lag of human capital $(\mathrm{SCH})$, have significant growth enhancing roles.

\section{Conclusion}

The main goal of this study is to investigate the effect of remittances relative to the other external sources of capital such as foreign aid and foreign direct investment on the economic growth and development of Sub-Saharan African countries. The results show that remittances do positively impact 
the economic growth of African countries. We have found that a 10 percent increase in remittances lead to a 0.3 percent increase in the GDP per capita income.

According to Gupta et al. (2007), remittances are neither a panacea nor a substitute for a sustained and domestically engineered development endeavor for curing the problems of low- income countries. Furthermore, large-scale migration can have a deleterious effect on domestic labor markets in specific sectors such as higher education, government services, science and technology, and the manufacturing and services, especially where those migrating to other countries are largely skilled workers who are difficult and expensive to replace. Migrant transfers in the form of remittances can ease the immediate budget constraints of families by bolstering crucial spending needs on food, health care, and schooling expenses for their children. Such an unharnessed market in money transfers is, not only a source of small scale saving, but it can also be expected to pave a way for the development of a formal financial sector which is essential for the economic growth and development of African countries in line with King and Levine (1993) and Beck, et al. (2000), Giuliano and Ruiz-Arrnz (2005), and Gupta, et al. (2007).

In addition, the results show that the conventional sources of growth such as investment in physical and human capital and the ability of households to have the wherewithal of spending on health, housing, nutrition, and other household items can enhance their productivity and spur their economic growth. A policy implication which may be drawn from this study is that African countries can improve their economic growth performance, not only by investing on the traditional sources of growth such as investment in physical and human capital, trade, and foreign direct investment, but also by strategically harnessing the contributions of remittances by ensuring their efficient and reliable transfers and reducing the cost of transfers by improving their governance performance. 


\section{References}

Adams, Richard H., 1991, "The Effects of International Remittances on Poverty, Inequality, and Development in Egypt," IFPRI Research Report 86 (Washington, IFPRI)

, 2006, "Remittances and Poverty in Ghana" World Bank Policy Research Paper 3838, (Washington: World Bank).

Arellano, M. and S. Bond, 1991, “Some Tests of Specification for Panel Data: Monte Carlo Evidence and an Application to Employment Equations," Review of Economic Studies, 58, 277-297.

Barro, R.J., 1990, "Government Spending in a Simple Model of Endogenous Growth," Journal of Political Economy, 98:.S103-25.

Barro, R.J. and X. Sala-i-Martin, 1992, "Public Finance in Models of Economic Growth," Review of Economic Studies, 54:646-61.

Barro, R., 1991, "Economic Growth in Cross-Section of Countries," Quarterly Journal of Economics, 106(May): 407-443.

Beck, T., R. Levine, and N. Loayza, 2000, Finance and Sources of Economic Growth," Journal Financial Economics, 58: 263-300.

Blomstrom, Mangnus, Richard Lipsey, and Mario Zejan, The Quarterly Journal of Economics, 111(1): 269-276.

Boone, Peter, 1994, "The Impact of Foreign Aid on Savings and Growth," Center Economic Performance, Working Paper, London School of Economics, No. 677, 1994.

Casseli, Francesco, Gerardo Esuivel, and Fernando Lefort, 1996, "Reopening the Convergence Debate: A New Look at Cross-country Growth empirics," Journal of Economic Growth, 1 (September): 363-389.

Chenery, H. B. and A. Strout, 1966, "Foreign Assistance and Economic Development," American Economic Review, 56 (September):679-733.

de Mello, L. R., 1999, "Foreign Direct Investment-led Growth: Evidence from Time Series Panel Data," Oxford Economic Papers, 51 (1)"133-151.

Denison, E. F., 1967, Why Growth Rates Differ: Post-War Experience for Nine Western 
Countries, Washington: DC.

Easterly, William and Ross Levine, 1997, “Africa's Growth Tragedy: Policies and Ethnic Divisions," The Quarterly Journal of Economics, 112 (4): 1203- 1250. , 2001, The Elusive Quest for Growth, The MIT Press, Cambridge, MA.

Fields, G. S., 1980, Poverty, Inequality, and Development, Cambridge University Press, Cambridge, England.

Fayissa, Bichaka and Mohammed El- Kaissy. (1999). "Foreign aid and the economic growth of developing countries (LDCs): Further Evidence," Studies in Comparative International Development, 37, (September, 1999): 37-50.

Giuliano, P. and M. Ruiz-Arranz, 2005, "Remittances, Financial Development, and Growth,” IMF Working Papers, WP/05/234, ftp://repec.iza.org/RePEc/ Discussionpaper/p2160.pdf

Gupta, Sanjeev, Catherine Pattillo, and Smita Wagh, 2007, "Making Remittances Work for Africa," Finance \& Development, 44, No. 2 (June, 2007): 1-9.

Hansen, H. and J. Rand, 2006, "On the Causal Links Between FDI and Growth in Developing Countries," http://www.blackwell-synergy.com/doi/pdf/10.1111/j.1467-9701.2006.00756.x

Harris, J. R. M. Todaro, 1970, "Migration, Employment, and Development: A TwoSector Analysis, American Economic Review, 60 (March):126-142.

Institute of Development Studies, 2006, http://www.id21.org/insights/insights60/art03.html

Islam, N. 1992, "Foreign Aid and Economic Growth: An Econometric Study of Bangladesh," Applied Economics, 24:541-544.

Kaufmann, Daniel, Aart Kraay, and Massimo Mastruzzi, 2007, "Governance Matters VI: Governance Indicators for 1996-2006," (July 2007), World Bank Policy Research, Washington, DC.

King, R. and R. Levine, 1993, "Finance, Entrepreneurship, and Growth,” Journal of Monetary Economics, 32: 513-542.

Levine, Roos, and David Renelt, 1992, "A Sensitivity Analysis of Cross-Country growth Regressions," American Economic review, 82, (September): 942-963.

Levy, Victor, 1987, "Aid and economic growth in the sub- Saharan: Africa: The recent experience," European Economic Review, 32; 1777-1795.

Lewis, A.W., 1954, "Economic Development with Unlimited Supplies of Labor," Manchester School of Economic and Social Studies, 22, (May): 139-191.

Lucas, R.E, 1988, "On Mechanics of Economic Growth," Journal of monetary Economics, 22 (July):3-42. 
Myrdal, G. 1968, Asian Drama: An Inquiry into the Poverty of Nations, (New York: Twentieth Century Fund).

Owens, E., 1987, The Future of Freedom in the Developing World, Pergamon Press.

Papanek, Gustav, 1973, "Aid, Foreign Private Investment, Savings, and Growth in Less Developing Countries," Journal of Political Economy, 81:120-130.

Romer, P., 1986, "Increasing Returns and Long-Run Growth," Journal of Political Economy, (October): 1002-1037.

Schultz, T.W., 1980, “The Economics of Being Poor," Journal of political Economy, (August): 639-651.

Sen A., 1999, Development as Freedom, Alfred Knopf Publisher (New York: NY).

Solow, R., 1956, “A Contribution to the Theory of Economic Growth," Quarterly Journal of Economics, 70(February): 65-94.

Stahl, Charles W. and Fred Arnold, 1986), “Overseas Workers' Remittances in Asian Development," International Migration Review, 20 (4): 899-925.

Temple, J. R. W., 1999, “The New Growth Evidence,” Journal of Economic Literature, 37 (March 1999):112-156.

World Bank, 2006, Global Economic Prospects: Economic Implications and Migration: Washington, DC). 
Table 1: Data Description and Summary Statistics

\begin{tabular}{|c|c|c|c|c|c|}
\hline & & \multicolumn{3}{|c|}{ Std. } & \\
\hline Variable & Description & Mean & Dev. & Min & Max \\
\hline GDPPC & GDP per capita (constant 2000 US\$) & 824.78 & 1098.95 & 85.79 & 7164.45 \\
\hline REM & $\begin{array}{l}\text { Per capita workers' remittances and } \\
\text { compensation of employees, received (US\$) }\end{array}$ & 28.91 & 49.83 & 0.00 & 250.45 \\
\hline ENR & Gross Enrollment rate (\%) (secondary) & 30.52 & 23.03 & 5.24 & 92.36 \\
\hline GCF & Gross fixed capital formation ( $\%$ of GDP) & 20.72 & 8.11 & 4.84 & 59.00 \\
\hline AID & $\begin{array}{l}\text { Official development assistance and official } \\
\text { aid (current millions of US\$) }\end{array}$ & 377 & 437 & 12 & 3800 \\
\hline TOT & Net barter terms of trade $(2000=100)$ & 110.03 & 35.98 & 44.40 & 252.21 \\
\hline FDI & $\begin{array}{l}\text { Foreign direct investment, net inflows (\% of } \\
\text { GDP) }\end{array}$ & 1.75 & 3.12 & 0.00 & 26.75 \\
\hline PRI & Political Rights Index & 4.93 & 1.63 & 1.00 & 7.00 \\
\hline INY & Initial Per Capita Income (GDPPC 1980) & 712.66 & 847.54 & 103.11 & 4670.10 \\
\hline
\end{tabular}

Notes: All data are transformed into logs for our analysis. Data is averaged over 5 year periods between 1994 and 2004 
Table 2: Estimation Results for Random effects and Quasi-Fixed Effects Models

\begin{tabular}{|c|c|c|c|c|c|}
\hline Variable & Description & \multicolumn{2}{|l|}{ Model 1} & \multicolumn{2}{|l|}{ Model 2} \\
\hline Constant & Intercept & $\begin{array}{r}0.320 \\
(0.567)\end{array}$ & & $\begin{array}{r}0.606 \\
(0.629)\end{array}$ & \\
\hline$R E M$ & $\begin{array}{l}\text { Per capita workers' remittances and compensation } \\
\text { of employees, received (US\$) }\end{array}$ & $\begin{array}{r}0.038 \\
(0.009)\end{array}$ & *** & $\begin{array}{r}0.036 \\
(0.015)\end{array}$ & $* *$ \\
\hline ENR & $\begin{array}{l}\text { Gross Enrollment rate }(\% \text { gross }) \text { (secondary }+ \\
\text { tertiary) }\end{array}$ & $\begin{array}{r}0.157 \\
(0.033)\end{array}$ & $* * *$ & $\begin{array}{r}0.199 \\
(0.047)\end{array}$ & $* * *$ \\
\hline$G C F$ & $\log$ Gross fixed capital formation ( $\%$ of GDP) & $\begin{array}{r}0.106 \\
(0.052)\end{array}$ & $* *$ & $\begin{array}{r}0.070 \\
(0.063)\end{array}$ & \\
\hline$A I D$ & $\begin{array}{l}\text { Official Development Assistance and Official Aid (Current } \\
\text { US \$) }\end{array}$ & $\begin{array}{r}-0.033 \\
(0.021)\end{array}$ & & $\begin{array}{r}-0.055 \\
(0.023)\end{array}$ & $* *$ \\
\hline TOT & $\log$ Net barter terms of trade $(2000=100)$ & $\begin{array}{r}0.091 \\
(0.075)\end{array}$ & & $\begin{array}{r}0.132 \\
(0.076)\end{array}$ & * \\
\hline$F D I$ & Foreign direct investment, net inflows (\% of GDP) & $\begin{array}{r}0.012 \\
(0.001)\end{array}$ & & $\begin{array}{r}0.011 \\
(0.012)\end{array}$ & \\
\hline$P R I$ & Political Rights Index & $\begin{array}{r}-0.134 \\
(0.045)\end{array}$ & $* * *$ & $\begin{array}{c}-0.068 \\
(0.045)\end{array}$ & \\
\hline$I N Y$ & Initial Per Capita Income (GDPPC 1980) & $\begin{array}{r}0.876 \\
(0.032)\end{array}$ & *** & $\begin{array}{r}0.849 \\
(0.047)\end{array}$ & $* * *$ \\
\hline Observati & & 139 & & 139 & \\
\hline R-Squarec & & 0.967 & & 0.965 & \\
\hline
\end{tabular}

Notes: Model 1 presents estimates for the quasi-fixed model with panel specific heteroskedasticity corrected standard errors; Model 2 presents estimates for random effects with bootstrap standard errors. The standard Errors In Parenthesis; $* * *, * *$, and $*$ indicate significance at $\mathrm{p}<0.01, \mathrm{p}<0.05$, and $\mathrm{p}<0.1$ levels, respectively. Number of observations $=185$. 
Table-3: Arellano-Bond Dynamic Panel-Data Estimation-Results

\begin{tabular}{|c|c|c|}
\hline \multirow{2}{*}{$\begin{array}{l}\text { Variables } \\
G D P\end{array}$} & \multicolumn{2}{|c|}{$\begin{array}{c}\text { Coefficient Estimates } \\
\text { (One-Step and One-Year } \\
\text { Lag) }\end{array}$} \\
\hline & & \\
\hline (LD) & $\begin{array}{r}0.850 \\
(0.030)\end{array}$ & *** \\
\hline$R E M(\mathrm{D}(1))$ & $\begin{array}{r}0.007 \\
-0.004\end{array}$ & * \\
\hline $\operatorname{ENR}(\mathrm{D}(1))$ & $\begin{array}{r}0.006 \\
(0.007)\end{array}$ & \\
\hline ENR & & \\
\hline (LD) & $\begin{array}{r}0.045 \\
(0.007)\end{array}$ & $* * *$ \\
\hline$G C F(\mathrm{D}(1))$ & $\begin{array}{r}0.060 \\
(0.013)\end{array}$ & $* * *$ \\
\hline$A I D$ & & \\
\hline$(\mathrm{D}(1))$ & $\begin{array}{r}-0.005 \\
(0.005)\end{array}$ & \\
\hline$T O T(\mathrm{D}(1))$ & $\begin{array}{r}0.001 \\
(0.018)\end{array}$ & \\
\hline$F D I$ & & \\
\hline$(\mathrm{D}(1))$ & $\begin{array}{r}0.000 \\
(0.001)\end{array}$ & \\
\hline$F D I(\mathrm{LD})$ & $\begin{array}{r}0.001 \\
(0.001)\end{array}$ & \\
\hline $\begin{array}{l}P R I \\
(\mathrm{D}(1))\end{array}$ & $\begin{array}{r}-0.016 \\
(0.028)\end{array}$ & \\
\hline Constant & $\begin{array}{r}0.695 \\
(0.127) \\
\end{array}$ & \\
\hline Number of Observations & 573 & \\
\hline Number of Countries & 37 & \\
\hline Wald Chi-Square & 2681 & $* * *$ \\
\hline Arellano-Bond Test of the null of No AR(1) Residual Errors & -1.95 & $* * *$ \\
\hline
\end{tabular}


Arellano-Bond test of the null of No AR(2) Residual Errors

Notes: Standard Errors In Parenthesis; ${ }^{* *},{ }^{* *}$, and * indicate significance at $\mathrm{p}<0.01, \mathrm{p}<0.05$, and $\mathrm{p}<0.1$ levels, respectively. While the suffix $\mathrm{D}(1)$ after each variable denotes the number of times the specific variable was differenced. LD denotes the lagged difference. The variable $\mathrm{SCH}$ is treated as pre-Determined, while FDI is treated as an endogenous variable

Figure 2: Top 10 recipients of Remittances as a \% of GDP

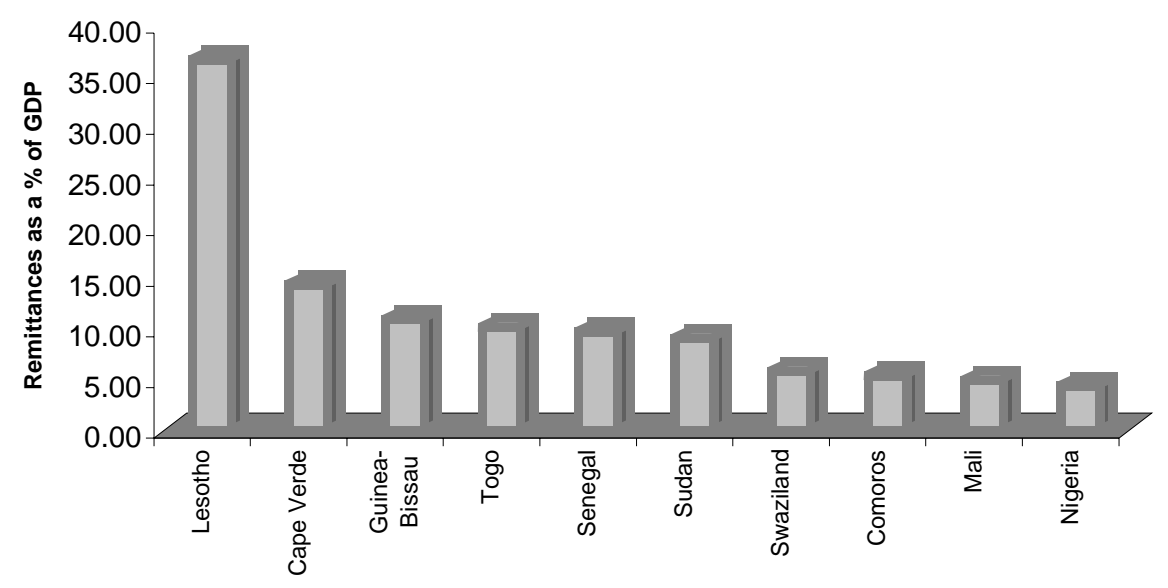

Source: World Development Report 